\title{
The use of ultrasonography in the diagnosis of nail disease among patients with psoriasis and psoriatic arthritis: a systematic review
}

\author{
José Alexandre Mendonça ${ }^{1 *}$, Sibel Zehra Aydin² and Maria-Antonietta D'Agostino 3,4
}

\begin{abstract}
Background: Nail involvement has been described as a key clinical feature for both psoriasis (PsO) and psoriatic arthritis (PsA) and is an important risk factor in PsA. Thus, early diagnosis of nail involvement may be essential for better management of PsO and PsA. Ultrasonography is considered a highly promising method to visualize nail disease. The main aim of this review was to evaluate the use of ultrasonography for the diagnosis of nail disease in patients with PsO and PsA by reviewing ultrasound parameters with the best diagnostic accuracy. Main body of the abstract: A systematic search was performed in MEDLINE via the PubMed and LILACS databases. Conference proceedings of relevant rheumatology scientific meetings were also screened.

Results: After applying eligibility criteria, only 13 articles and 5 abstracts were included in this review. The selected studies showed a huge variability in evaluation methods (and therefore in the results) and were mainly focused on the assessment of nails ultrasound parameters that may differ among patients and healthy controls, especially the morphological aspects in B-mode ultrasonography and vascularization of the nail bed by Doppler ultrasonography. Our research indicated that the evaluation of nail disease in PsO and PsA is still underrepresented in the literature, probably reflecting a restricted use in clinical practice, despite the widespread use of ultrasonography in the management of chronic arthritis.
\end{abstract}

Short conclusions: Despite the potential relevance of ultrasonography for the diagnosis of nail disease, additional studies are needed to determine which features are more reliable and clinically pertinent to ensure accuracy in the evaluation of nail involvement in PsO and PsA.

Keywords: Psoriasis, Psoriatic arthritis, Ultrasonography, Spectral Doppler, Power Doppler, Ungueal disease

\section{Background}

Psoriasis ( $\mathrm{PsO}$ ) is defined as a chronic, immune-mediated, gene-based disease with an inflammatory background that affects the skin, semi-mucosa, and joints. When joints and surrounding structures are involved, patients are classified as having psoriatic arthritis (PsA) [1-4]. The prevalence of $\mathrm{PsO}$ may range from 0.5 to $11.8 \%$ around the world [5-9], while the prevalence of PsA amongst patients with $\mathrm{PsO}$ varies from 5.9 to $48 \%$, according to the patient

\footnotetext{
* Correspondence: mendoncaja.us@gmail.com

${ }^{1}$ Department of Rheumatology and Postgraduate Program of the Pontifical Catholic, University of Campinas, Rua da Fazenda, 125, Condomínio Dálias, casa 10, Residencial Vila Flora, Sumaré, São Paulo 13175665, Brazil Full list of author information is available at the end of the article
}

characteristics and classification criteria used $[1,3,4,8]$. $\mathrm{PsO}$ manifestations may vary; however, plaque $\mathrm{PsO}$ (or psoriasis vulgaris) is the most frequent skin phenotype, affecting approximately $90 \%$ of patients with $\mathrm{PsO}$ [9]. The disease may also affect the scalp, joints, creases, or nails, even in patients without skin lesions [10].

Fifty to $80 \%$ of patients with $\mathrm{PsO}$ have concurrent nail lesions [11-13], which can lead to functional impairment, pain and discomfort, and decreased quality of life and general well-being [14, 15]. Despite its significant prevalence (around $50 \%$ of patients), nail manifestations are often neglected in daily clinical practice, probably

(c) The Author(s). 2019 Open Access This article is distributed under the terms of the Creative Commons Attribution 4.0 International License (http://creativecommons.org/licenses/by/4.0/), which permits unrestricted use, distribution, and 
due to a lack of recognition of its impact on patients or its relevance as an indicator of disease extension [15].

Psoriatic arthritis leads to impairments in a patient's life, decreasing functional capacity and quality of life, which also increases the burden of disease to society. This burden highlights the need for early diagnosis and timely treatment for all comorbidities. In this sense, nail disease has been reported as a relevant risk factor for PsA [16] and may be employed as an early diagnostic parameter among patients with $\mathrm{PsO}$.

Imaging techniques such as ultrasonography (US) have been increasingly used to diagnose and to monitor clinical features of PsO and PsA [17-20]. US findings usually include measures of thickness of the nail bed and the ventral and dorsal plates, as well as loss of definition, morphologic changes, and blood flow disturbances [21, 22]. Power Doppler (PD) and spectral Doppler (SD) are US techniques that are used to visualize nail inflammation. PD semiquantitatively shows nail inflammation through the detection of increased flow in blood vessels, whereas SD calculates the resistive index (RI) using systolic and diastolic peak flows of small vessels, which expresses the resistance to blood flow in the nail bed [22, 23]. Despite the relevance of US, discordant data are available on the usefulness of Doppler techniques for the evaluation of nail disease in PsO and PsA. Thus, the aims of this review are (i) to investigate the usefulness of nail US for the diagnosis of nail disease in patients with $\mathrm{PsO}$ and PsA; (ii) to gather data about parameters obtained through Doppler techniques (PD and SD) indicating inflammation of the nail bed, including but not limited to RI and vascularization of the nail unit; and (iii) to observe the differences between PsO, PsA, and healthy controls in RI and morphologic changes.

\section{Main text Methods}

A systematic search was performed using MEDLINE via PubMed and LILACS (Latin American and Caribbean Health Sciences Literature) in order to identify studies addressing the use of US in nail assessment in terms of variables relevant in the context of $\mathrm{PsO}$ and $\mathrm{PsA}$, to meet the previously mentioned goals. Two search strategies using a combination of controlled vocabulary (MeSH and DeCs keywords, for Pubmed and LILACS, respectively) and text words were adopted, as shown in Table 1. Searches were performed until March 20, 2018.
Conference proceedings of relevant scientific meetings in rheumatology (European League Against Rheumatism and American College of Rheumatology, as selected by the authors) were also screened. Only studies published during the past 10 years were considered eligible. Language selection was made manually by the reviewers.

After applying the predefined search strategies, the records were screened by two different reviewers using the following inclusion criteria: i) observational or non-therapy interventional studies; ii) patients with $\mathrm{PsO}$ and/or PsA; iii) studies assessing the use of US for nail assessment; and iii) papers reported in English, French, Portuguese, and Spanish only. Studies were deemed noneligible if they consisted of any of the following exclusion criteria: i) clinical trials of any phase or study design or ii) case reports.

Initially, it was planned that in cases of discordance, a third reviewer would be the responsible for the final decision to include a selected article or not. No disagreements were identified in the review process; therefore, this strategy was unnecessary. Data extraction was performed by the reviewers, using a data collection tool specifically designed for this review. Variables abstracted from individual studies were: author, year, study design, sample size, baseline disease (if applicable), primary and secondary aims (if applicable), US assessments performed, nail parameters described, results. Assessment of bias was based on the Joanna Briggs Institute Critical Appraisal Instrument for Studies Reporting Prevalence Data $[24,25]$. The risk assessment tool is descriptive and does not provide scores.

\section{Results}

A total of 48 records were initially identified. After application of the eligibility criteria, 13 were selected and included in this review. In addition, five abstracts were manually identified in the conference proceedings searched (Fig. 1), which provided the final number of 18 studies analyzed.

The main characteristics of the 18 studies included in this review are summarized in Table 2.

\section{Assessment of bias}

The Joanna Briggs Institute Critical Appraisal Instrument for Studies Reporting Prevalence Data was applied to all of the included studies. In terms of sample frame and sampling, most studies used a clinic-based approach

Table 1 Search strategy

\begin{tabular}{ll}
\hline Database & Search Strategy \\
\hline PubMed & ("Arthritis, Psoriatic"[Mesh] OR "Psoriasis"[Mesh] OR "psoriatic arthritis" OR "psoriasis") AND ("Ultrasonography"[Mesh] OR "ultrasound" OR \\
& "Ultrasonography, Doppler"[Mesh] OR "Doppler" OR "Power doppler" OR "spectral") AND ("nail" OR "ungueal") \\
LILACS & $\begin{array}{l}\text { ("Psoríase" or "Psoriasis" or "Arthritis, Psoriatic" or "Artrite Psoriásica") and ("ultrasonography" or "ultrasound" or "ultrassonografia" or "doppler") } \\
\text { and ("unha" or "nail" or "ungueal") }\end{array}$ \\
\hline
\end{tabular}




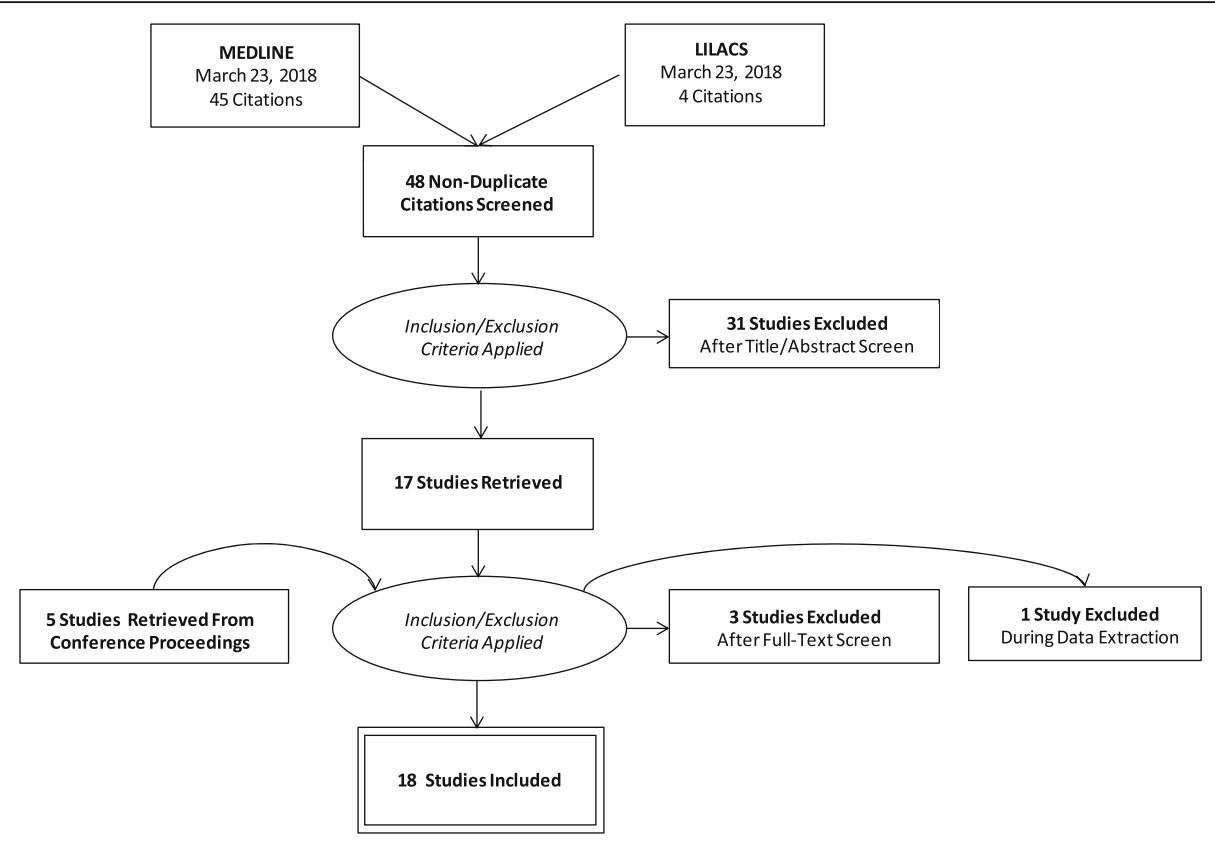

Fig. 1 PRISMA flowchart

and described how the potential participants were recruited. Sample sizes varied from 10 to 238 patients, and all of them relied upon convenience, without clearly stating a sample size calculation rationale. Study subjects were appropriately described in all included studies, and valid methods to determine the presence of the pathological condition were used and extensively described. The statistical analysis plan was deemed appropriate for the 15 studies [26-40]. Overall, the risk of bias was assessed as moderate to high due to the small sample size of the studies.

\section{Main findings of included studies}

After full text analysis of the 18 records included in the review, a wide range of variables and methodologic approaches was identified. Tables 3, 4, and 5 summarize the key features that are relevant to this systematic literature review. Due to the methodologic variability of the included studies (as shown in Table 2), comparability or further data pooling was deemed not feasible. The descriptive data regarding grey-scale features, presence of Doppler vascularity, and RI measurement of nails' vascularization are presented below.

Gray-scale features of the nail by ultrasonography Twelve studies reviewed gray-scale findings [26, 28-31, 33-39]. Three of these studies were only pictorial essays, which were purely descriptive [41-43]. The terminology that was used by different investigators to describe grayscale findings widely varied across studies, such as "loss of definition," "hyperechoic definition," "fusion," or "hyperechoic focal involvement of the ventral plate," all of which are likely to correspond to the loss of trilaminar appearance. The normal nail plate was usually described as "two hyperechoic white bands surrounding an anechoic well defined layer in between" and the lack of visibility of the latter anechoic layer may technically be named using one of these definitions. Although it was impossible to compare studies in the absence of a uniform definition, there were consistently more nail lesions as measured using US in patients with PsA (46-54\%) $[29,35]$ and $\mathrm{PsO}(48.8-77.8 \%)$ [33, 35-37] compared with healthy controls (10\%) [37]. In addition, patients with clinical nail disease were consistently found to have more lesions on US (57/101 [56.4\%] vs 6/68 [8.8\%]; $p<$ 0.0001 ) [37] and had more frequent ventral nail plate deposits (median, 17.72 [Q1-Q3 $=10.14-27.83]$ vs 4.65 [Q1-Q3 $=0.05-16.23$ ]; $p=0.0410$ ) [31]. US results have a good agreement with clinical assessment for nail disease (kappa value $=0.79$ for PsA patients and controls; $p<0.001$ ) [33] and also a strong correlation (chi-square test, 10.769 for PsA and osteoarthritis patients; $p=$ 0.001 ) [29]. However, it was not possible to confirm that US was more sensitive to detect nail disease versus clinical assessment. While there was higher number of nails with US features in the absence of clinical findings, there were also patients with positive clinical nail disease and no US features [36]. Nails with a false negative US test had mainly mild lesions, such as onycholysis or pitting with lower modified nail psoriasis severity index (mNAPSI, a psoriatic nail grading instrument used to 


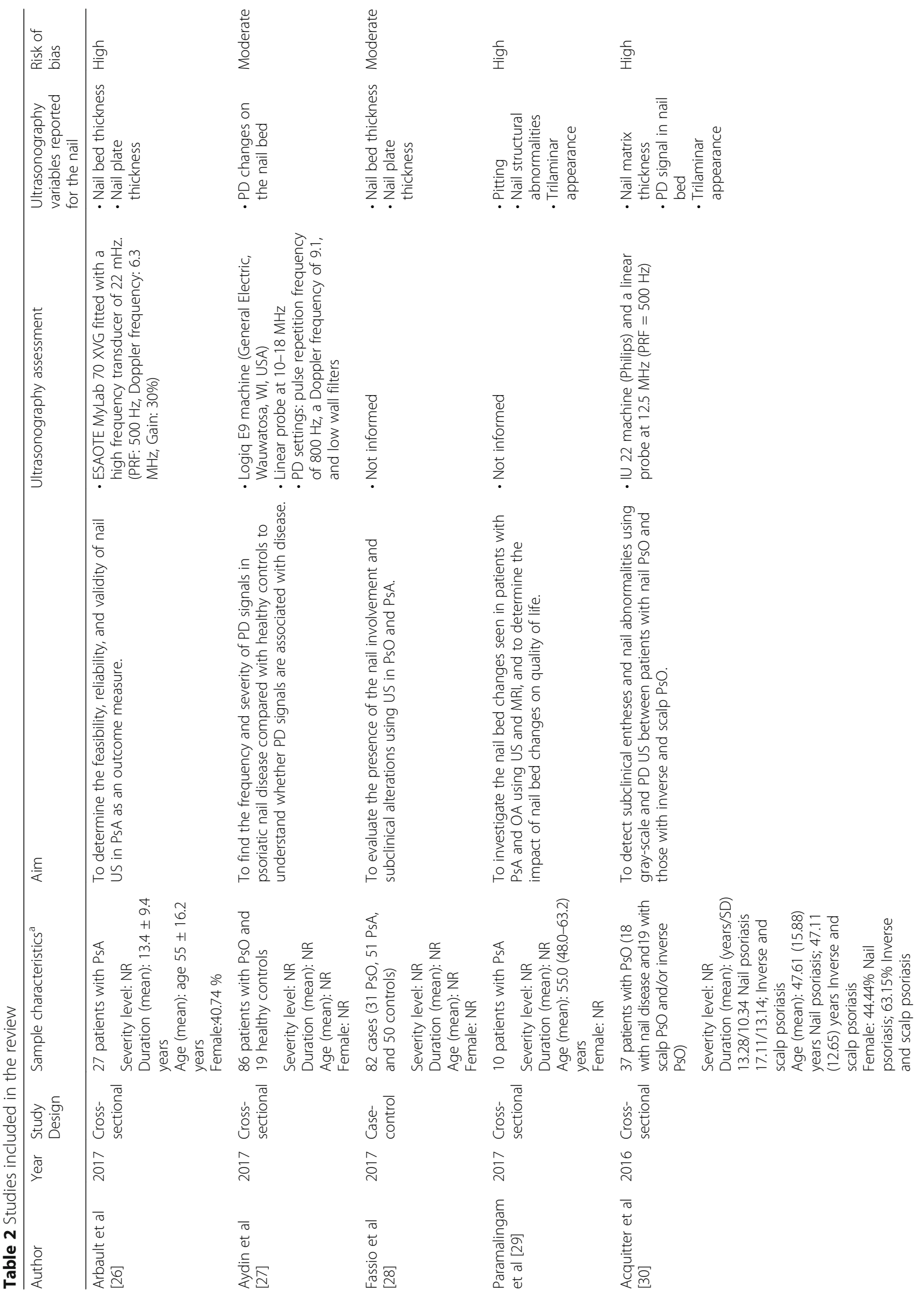




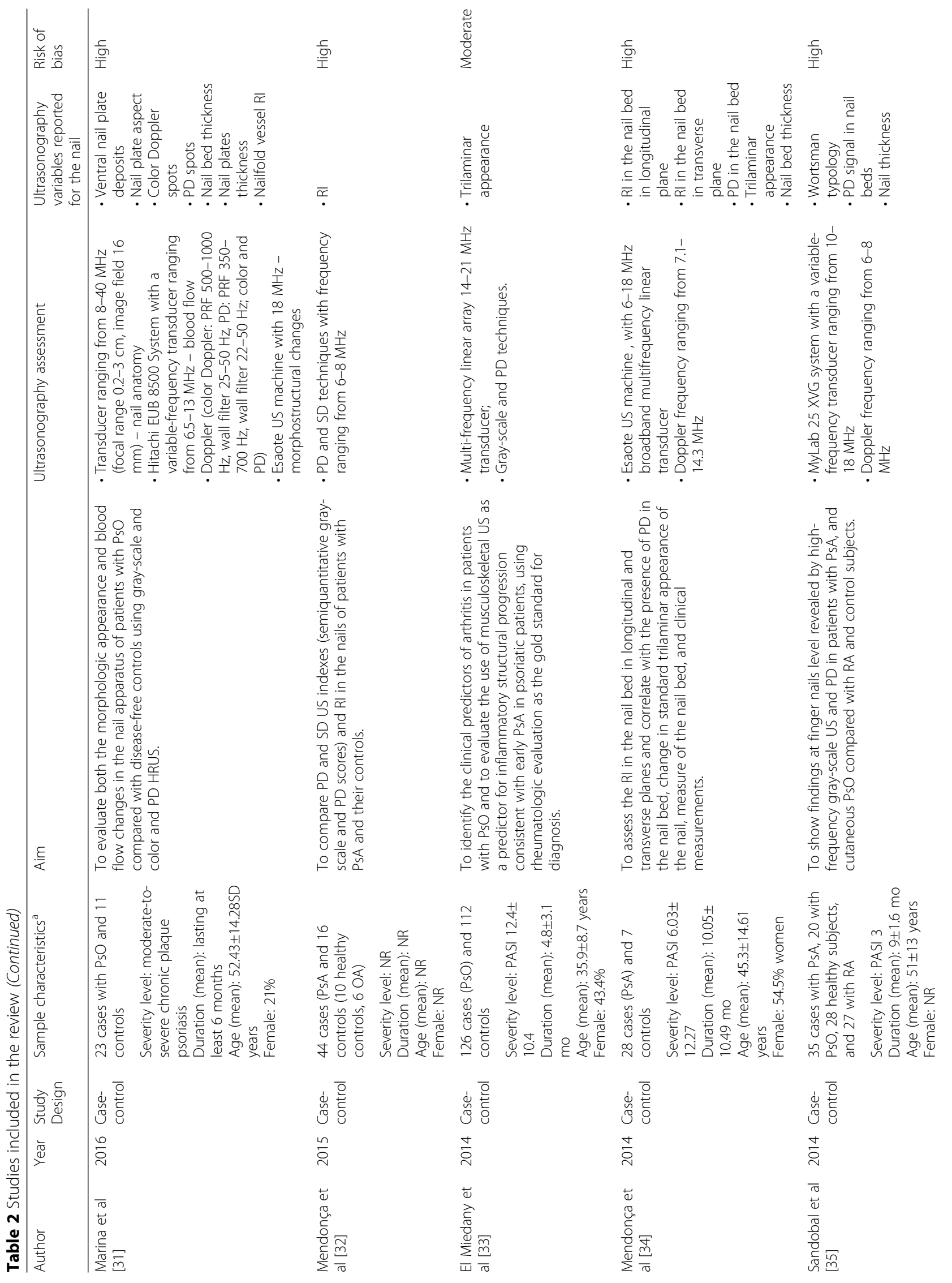




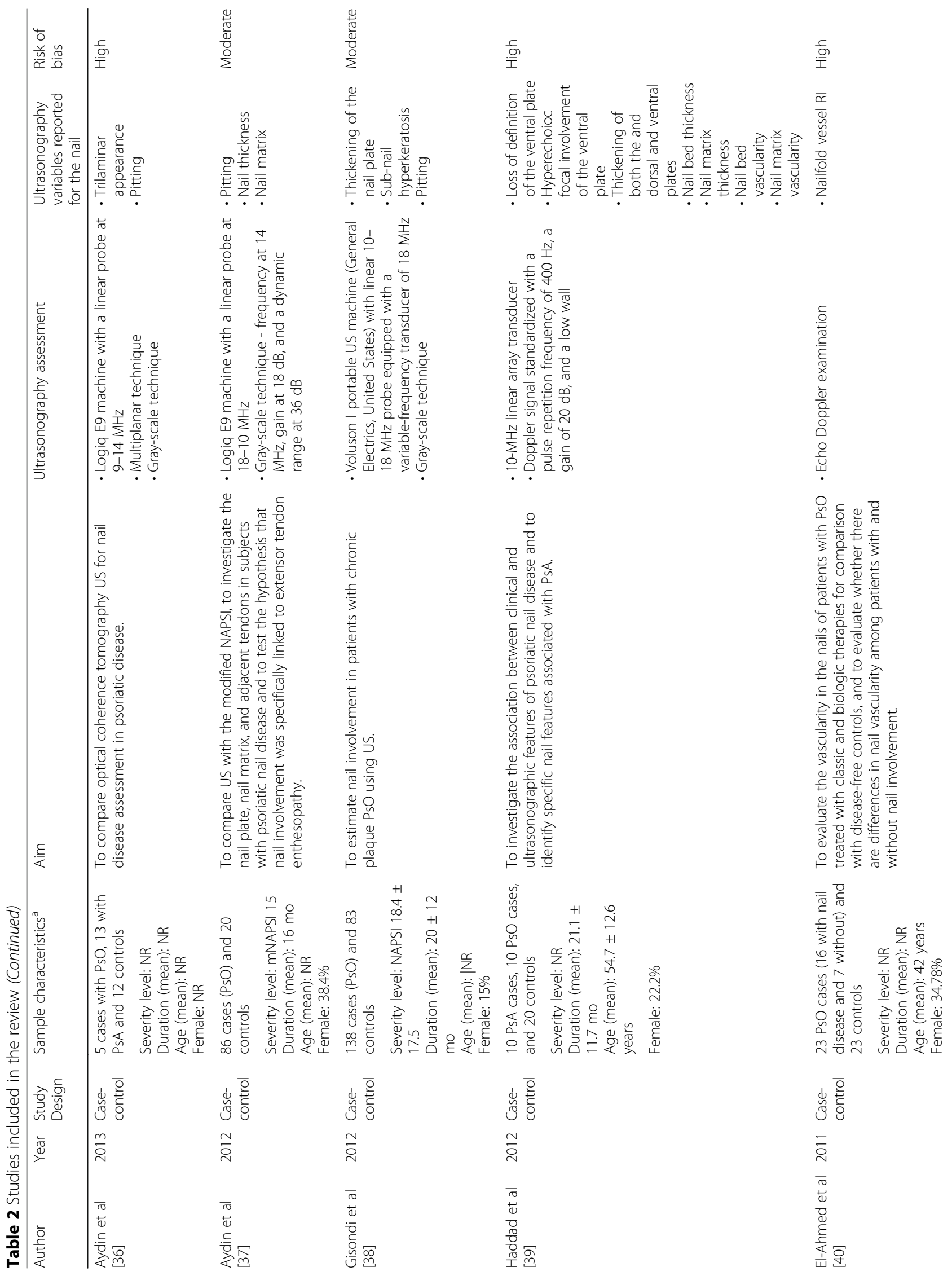




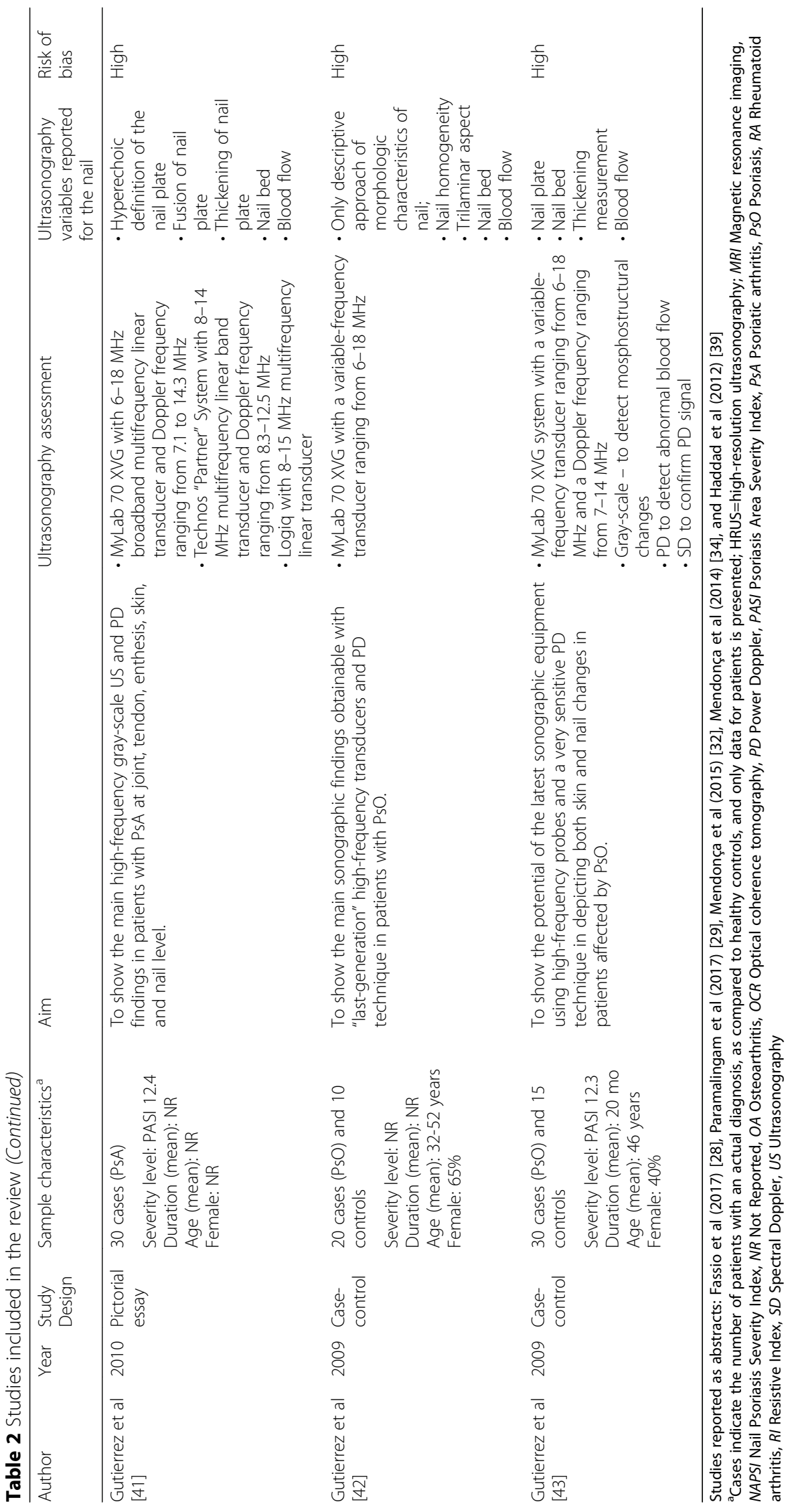


Table 3 Studies comprising measurements on gray-scale ${ }^{a}$

\begin{tabular}{|c|c|c|c|}
\hline Studies & Population & Gray-scale & Result \\
\hline Arbault et al. (2017) [26] & PsA & $\begin{array}{l}\text { Nail bed thickness } \\
\text { Mean (SD): } 0.5 \mathrm{~mm}(0.04) \\
\text { Nail plate thickness } \\
\text { Mean (SD): } 2.0 \mathrm{~mm}(0.42)\end{array}$ & - \\
\hline \multirow[t]{3}{*}{ Fassio et al. (2017) [28] } & $\mathrm{PsO}$ & $\begin{array}{l}\text { Nail bed thickness } \\
\text { Mean (SD): } 0.25 \mathrm{~mm}(0.05) \\
\text { Nail plate thickness } \\
\text { Mean (SD): } 0.063 \mathrm{~mm}(0.011)\end{array}$ & \multirow[t]{3}{*}{ Healthy controls had lower nail plate and nail bed thickness. } \\
\hline & PsA & $\begin{array}{l}\text { Nail bed thickness } \\
\text { Mean (SD): } 0.25 \mathrm{~mm}(0.04) \\
\text { Nail plate thickness } \\
\text { Mean (SD): } 0.065 \mathrm{~mm}(0.014)\end{array}$ & \\
\hline & Controls & $\begin{array}{l}\text { Nail bed thickness } \\
\text { Mean (SD): } 0.22 \mathrm{~mm}(0.02) \\
\text { Nail plate thickness } \\
\text { Mean (SD): } 0.051 \mathrm{~mm}(0.006)\end{array}$ & \\
\hline \multirow[t]{2}{*}{ Acquitter et al. (2016) [30] } & $\begin{array}{l}\text { Patients with PsO } \\
\text { with nail disease }\end{array}$ & $\begin{array}{l}\text { Nail matrix thickness } \\
\text { Median (SD): } 1.94 \text { mm (0.69) }\end{array}$ & \multirow{2}{*}{$\begin{array}{l}\text { Patients with } \mathrm{PsO} \text { with nail disease presented with significantly } \\
\text { higher nail matrix thickness than patients with scalp PsO and/or } \\
\text { inverse } \mathrm{PsO}(p<0.01) \text {. }\end{array}$} \\
\hline & $\begin{array}{l}\text { Patients with scalp } \\
\mathrm{PsO} \text { and/or inverse PsO }\end{array}$ & $\begin{array}{l}\text { Nail matrix thickness } \\
\text { Median (SD): } 1.77 \text { mm (0.54) }\end{array}$ & \\
\hline \multirow[t]{2}{*}{ Marina et al. (2016) [31] } & $\mathrm{PsO}$ & $\begin{array}{l}\text { Nail bed thickness } \\
\text { Median (IQR): } 1.88 \mathrm{~mm} \\
\text { (1.71-2.03) } \\
\text { Nail plate thickness } \\
\text { Median (IQR): } 0.86 \mathrm{~mm}(0.60- \\
1.14)\end{array}$ & \multirow[t]{2}{*}{$\begin{array}{l}\text { Healthy controls had a statistically significant lower nail plate } \\
\text { thickness than patients with } \mathrm{PsO}(p<0.0001) \text {. No significant } \\
\text { differences were observed in nail bed thickness variability } \\
\text { among groups }(p=0.4621) \text {. }\end{array}$} \\
\hline & Controls & $\begin{array}{l}\text { Nail bed thickness } \\
\text { Median (IQR): } 1.89 \mathrm{~mm}(1.78- \\
2.00) \\
\text { Nail plate thickness } \\
\text { Median (IQR): } 0.63 \mathrm{~mm}(0.59- \\
0.67)\end{array}$ & \\
\hline \multirow[t]{2}{*}{ Mendonça et al. (2014) [34] } & PsA & $\begin{array}{l}\text { NGS } \\
\text { Mean (SD): } 0.48 \text { mm (0.50) }\end{array}$ & \multirow[t]{2}{*}{ Healthy controls had lower NGS than patients with PSA. } \\
\hline & Controls & $\begin{array}{l}\text { NGS } \\
\text { Mean (SD): } 0.00 \text { mm (0.00) }\end{array}$ & \\
\hline \multirow[t]{2}{*}{ Aydin et al. (2012) [37] } & $\mathrm{PsO}$ & $\begin{array}{l}\text { Nail thickness } \\
\text { Median (range): } 0.56 \text { mm (0.3- } \\
\text { 1.9) }\end{array}$ & \multirow[t]{2}{*}{ Healthy controls had slightly lower NGS than patients with PsO. } \\
\hline & Controls & $\begin{array}{l}\text { Nail thickness } \\
\text { Median (range): } 0.5 \mathrm{~mm} \\
(0.3-0.6)\end{array}$ & \\
\hline Gisondi et al. (2012) [38] & $\mathrm{PsO}$ & $\begin{array}{l}\text { Nail plate thickness } \\
70 \text { patients (50\%) }\end{array}$ & - \\
\hline \multirow[t]{3}{*}{ Haddad et al. (2012) [39] } & $\mathrm{PsO}$ & $\begin{array}{l}\text { Nail bed thickness } \\
\text { Mean (SD): } 16.0 \mathrm{~mm}(2.9) \\
\text { Nail matrix thickness } \\
\text { Mean (SD): } 17.5 \mathrm{~mm} \text { (2.9) }\end{array}$ & \multirow{3}{*}{$\begin{array}{l}\text { Comparing the three groups, patients with PsO and PsA } \\
\text { presented with statistically significant higher values of nail bed } \\
\text { thickness and nail matrix thickness than controls ( } p<0.0001) \text {. } \\
\text { Comparing patients with PsO and PsA, patients with PsO } \\
\text { presented with a significantly lower nail matrix thickness than } \\
\text { patients with PsA ( } p=0.002) \text {. No statistically significant differences } \\
\text { were observed in nail bed thickness among those groups } \\
(p=0.81) \text {. }\end{array}$} \\
\hline & PsA & $\begin{array}{l}\text { Nail bed thickness } \\
\text { Mean (SD): } 15.9 \mathrm{~mm} \text { (3.0) } \\
\text { Nail matrix thickness } \\
\text { Mean (SD): } 18.8 \mathrm{~mm} \text { (3.0) }\end{array}$ & \\
\hline & Controls & $\begin{array}{l}\text { Nail bed thickness } \\
\text { Mean (SD): } 14.1 \mathrm{~mm}(1.2) \\
\text { Nail matrix thickness } \\
\text { Mean (SD): } 15.8 \mathrm{~mm}(0.92)\end{array}$ & \\
\hline
\end{tabular}


Table 4 Studies comprising quantitative results on $\mathrm{PD}^{\mathrm{a}}$

\begin{tabular}{|c|c|c|c|}
\hline Studies & Population & PD & Results \\
\hline \multirow[t]{2}{*}{ Aydin et al. (2017) [27] } & $\mathrm{PsO}$ & NPD: $84.6 \%$ & \multirow{2}{*}{$\begin{array}{l}\text { Presence of nail bed with PD signal was similar among patients } \\
\text { with PsO and healthy controls. }\end{array}$} \\
\hline & Controls & NPD: $81.6 \%$ & \\
\hline \multirow[t]{2}{*}{ Paramalingam et al. (2017) [29] } & PsA & NPD: $96.0 \%$ & \multirow{2}{*}{$\begin{array}{l}\text { Patients with PsA presented with a slightly higher percentage } \\
\text { of nails with PD signal than patients with OA. }\end{array}$} \\
\hline & $\mathrm{OA}$ & NPD: $95.0 \%$ & \\
\hline \multirow[t]{2}{*}{ Acquitter et al. (2016) [30] } & $\begin{array}{l}\text { Patients with } \mathrm{PsO} \\
\text { with nail disease }\end{array}$ & NPD: $44.5 \%$ & \multirow[t]{2}{*}{$\begin{array}{l}\text { NPD was higher in patients with PsO with nail disease; howeve } \\
\text { differences among groups were not significant. }\end{array}$} \\
\hline & $\begin{array}{l}\text { Patients with scalp } \\
\mathrm{PsO} \text { and/or inverse } \mathrm{PsO}\end{array}$ & NPD: $39.0 \%$ & \\
\hline \multirow[t]{2}{*}{ Mendonça et al. (2014) [34] } & PsA & NPD mean (SD): 0.88 (0.31) & \multirow[t]{2}{*}{ NPD was slightly lower in patients with PsA than controls. } \\
\hline & Controls & NPD mean (SD): $1.0(0.00)$ & \\
\hline \multirow[t]{4}{*}{ Sandobal et al. (2014) [35] } & $\mathrm{PsO}$ & $\begin{array}{l}\text { Increase PD signal in nail } \\
\text { beds: } 20.5 \%\end{array}$ & \multirow[t]{4}{*}{$\begin{array}{l}\text { Patients with psoriatic arthropathy showed increased PD } \\
\text { signal in nail bed }(p=0.0001) \text {. }\end{array}$} \\
\hline & PsA & $\begin{array}{l}\text { Increase PD signal in nail } \\
\text { beds: } 23.4 \%\end{array}$ & \\
\hline & RA & $\begin{array}{l}\text { Increase PD signal in nail } \\
\text { beds: } 2.2 \%\end{array}$ & \\
\hline & Controls & $\begin{array}{l}\text { Increase PD signal in nail } \\
\text { beds: } 19.6 \%\end{array}$ & \\
\hline \multirow[t]{3}{*}{ Haddad et al. (2012) [39] } & $\mathrm{PsO}$ & Nail bed vascularity: $14 \%$ & \multirow{3}{*}{$\begin{array}{l}\text { Comparing the three groups, patients with } \mathrm{PsO} \text { and PsA } \\
\text { presented with statistically significantly lower values of nail } \\
\text { bed vascularity than controls }(p<0.001) \text {. } \\
\text { Comparing patients with PsO and PsA, patients with PsO } \\
\text { presented with lower nail bed vascularity than patients with } \\
\text { PsA; however, no statistically significant differences were } \\
\text { observed }(p=0.44) \text {. }\end{array}$} \\
\hline & PsA & Nail bed vascularity: $18 \%$ & \\
\hline & Controls & Nail bed vascularity: $20 \%$ & \\
\hline
\end{tabular}

NPD presence of power Doppler in the nail bed, OA osteoarthritis, $P D$ power Doppler, $P S A$ psoriatic arthritis, $P S O$ psoriasis, $R /$ Resistive Index, $S D$ standard deviation ${ }^{a}$ Only studies with quantitative results regarding nail thickness, trilaminar appearance, presence of PD signal, and nail RI were included in this table

Table 5 Studies comprising quantitative results on spectral Doppler ${ }^{a}$

\begin{tabular}{|c|c|c|c|}
\hline Studies & Population & Spectral Doppler & Results \\
\hline \multirow[t]{2}{*}{ Marina et al. (2016) [31] } & $\mathrm{PsO}$ & $\begin{array}{l}\text { NVRI } \\
\text { Median (IQR): } \\
0.62(0.55-0.69)\end{array}$ & \multirow[t]{2}{*}{$\begin{array}{l}\text { Patients with PsO presented with significantly higher median } \\
\text { NVRI measurements than controls }(p<0.0001)\end{array}$} \\
\hline & Controls & $\begin{array}{l}\text { NVRI } \\
\text { Median (IQR): } \\
0.57(0.55-0.58)\end{array}$ & \\
\hline \multirow[t]{2}{*}{ Mendonça et al. (2014) [34] } & PsA & $\begin{array}{l}\text { LRI } \\
\text { Mean (SD): } 0.50(0.13) \\
\text { TRI } \\
\text { Mean (SD): } 0.48(0.09)\end{array}$ & \multirow[t]{2}{*}{$\begin{array}{l}\text { Rl measurements in both the transverse and longitudinal } \\
\text { planes were lower for patients with PsA than controls. }\end{array}$} \\
\hline & Controls & $\begin{array}{l}\text { LRI } \\
\text { Mean (SD): } 0.86(0.41) \\
\text { TRI } \\
\text { Mean (SD): } 0.70(0.16)\end{array}$ & \\
\hline \multirow[t]{4}{*}{ El-Ahmed et al. (2011) [40] } & $\mathrm{PsO}$ & $\begin{array}{l}\text { NVRI } \\
\text { Mean (SD): } 0.56(0.09)\end{array}$ & \multirow{4}{*}{$\begin{array}{l}\text { The mean NVRI was significantly higher in PsO than controls } \\
(p<0.001) \text {. Patients with PsO with clinical nail disease had } \\
\text { also significantly higher NVRI than those without nail disease } \\
(p<0.05) \text {. }\end{array}$} \\
\hline & $\begin{array}{l}\text { Patients with } \mathrm{PsO} \\
\text { with nail disease }\end{array}$ & $\begin{array}{l}\text { NVRI } \\
\text { Mean (SD): } 0.58(0.10)\end{array}$ & \\
\hline & $\begin{array}{l}\text { Patients with } \mathrm{PsO} \\
\text { without nail disease }\end{array}$ & $\begin{array}{l}\text { NVRI } \\
\text { Mean (SD): } 0.52(0.45)\end{array}$ & \\
\hline & Controls & $\begin{array}{l}\text { NVRI } \\
\text { Mean (SD): } 0.42(0.04)\end{array}$ & \\
\hline
\end{tabular}


assess severity of nail matrix and bed $\mathrm{PsO}$ by area of involvement in the nail unit) than those with true (i.e., marked) abnormalities on US (median mNAPSI, 10 [1-56] vs 17 [1-50]; $p=0.03$ ), with a moderate absolute agreement between US and clinical assessment (76.3\% with $\mathrm{K}=0.52, p<0.0001$ ) [37].

The studies also investigated nail thickness using US, reporting an increased thickness of nail plate, bed, and matrix in patients with $\mathrm{PsO}$ and/or PsA compared with controls [26, 28, 30, 31, 37, 39] (Table 3). Marina et al. was not able to demonstrate a difference in nail bed thickness between patients with $\mathrm{PsO}$ and controls [31]. Comparing 2 groups with $\mathrm{PsO}$, one with nail disease and other with scalp PsO and/or inverse PsO, Acquitter et al. (2016) reported that the former group presented with statistically higher nail matrix thickness than patients in the latter group [30]. It was not possible to identify in the studies a comparison between $\mathrm{PsO}$ and PsA patients in terms of nail bed thickness with statistical significant differences.

Presence of vascularity within the nail unit by ultrasonography Nail bed PD signals were variable in both patients with $\mathrm{PsO}$ and PsA across the studies, with a range varying from 20 to $96 \%[27,29,30,35,44]$. A high frequency of vascularisation was also observed in healthy controls, ranging from 20 to $81.6 \%$ [27, 35]. Some studies demonstrated increased blood flow in patients with $\mathrm{PsO}[31,39]$. Comparing patients with $\mathrm{PsO}$ plus nails disease and patients with scalp $\mathrm{PsO}$ and/or inverse $\mathrm{PsO}$, a higher frequency of $\mathrm{PD}$ signal in the nail bed was found in the first group compared with the second group [30] (Table 4). PD signals were usually scored semiquantitavely on a scale between 0 and 3 . Interestingly, PsO was associated with all grades of PD signal severity [31]. On the contrary, Aydin et al. (2017) reported that a diagnosis of $\mathrm{PsO}$ was associated with a less frequent severe (grade 3) PD signal on the nail bed than in healthy controls (healthy controls vs $\mathrm{PsO}, 65.8 \%$ vs $34.9 \% ; p=0.002,27]$.

Resistive index measurements Three studies assessed RI measurements in patients with PsO or PsA compared with controls (Table 5) [31, 34, 40]. According to two of these studies, patients with $\mathrm{PsO}$ presented with statistically higher Nailfold Vessel RI (NVRI) measurements than healthy controls [31, 40]. Mendonça et al. (2014) assessed RI measurements in patients with PsA and reported that patients with PsA had lower RI measurements in both the nail bed in transverse and longitudinal planes than controls (PsA, mean of longitudinal plane measurement, $0.50 \pm 0.13$; mean of transverse plane measurement, $0.48 \pm 0.09$; controls, mean of longitudinal plane measurement, $0.86 \pm 0.41$; mean of transverse plane measurement, $0.70 \pm 0.16)$. In addition, RI measurements in the nail bed in the longitudinal plane were correlated with RI measurements in the nail bed in the transverse plane $(r=0.333$; $p=0.013)$ and with duration of medication use $(r=0.578$; $p=0.002)$ and was negatively correlated with the presence of PD in the nail bed $(r=-0.213 ; p=0.038)$. RI measurements in the nail bed in the transverse plane were not correlated with the presence of PD in the nail bed, while the measure of nail bed was correlated with the trilaminar appearance of nail $(r=0.472 ; p=0.023,34]$.

One study evaluated the sensitivity and specificity of RI measurements in patients with PsA [32]. In this study, patients with PsA presented statistically significant lower RI measurements than controls $(p<0.001)$, with high sensitivity and specificity for RI measurements in PSA patients (receiver operating characteristic curve $=0.858 ; p<0.01$ ). Patients with PsA and no symptoms of nail involvement also had lower RI measurements. Considering a 0.395 cutoff point for RI measurements, the results showed that RI measurements $<0.4$ points were associated with 100 and $99 \%$ of sensitivity and specificity, respectively, for ungueal inflammatory activity [32].

\section{Discussion}

This systematic review was conducted to evaluate the current knowledge about the use of US for the diagnosis of nail disease in patients with $\mathrm{PsO}$ and PsA. However, the heterogeneous methodologic approaches did not allow us to perform a comparison of studies.

Although US is a method of diagnosis widely used in clinical practice for several diseases including PsA, realworld data shows that the use of this technique for the diagnosis of nail disease is still scarcely investigated in the literature, probably reflecting that the techniques is not routinely used in patients with $\mathrm{PsO}$ and PsA. Enthesitis/enthesopathies, joint synovitis and effusion, bone changes, tenosynovitis, and dactylitis are the main pathologies examined by US in patients with $\mathrm{PsO}$ and PsA [21]. The selected studies were mainly focused on the assessment of parameters that can differentiate healthy subjects with and without $\mathrm{PsO}$ and patients with $\mathrm{PsO}$ and PsA with and without nail disease [28, 29, 31-43].

A lower Doppler signal in the nail bed was found as marker of nail disease in patients with $\mathrm{PsO}$ and PsA compared with healthy controls. However the selected studies showed a wide variability for the presence of Doppler signal in the nail unit, mostly due to differences in the US equipment sensitivity or other variables such as Doppler settings, experience of the observer, or room temperature [29, 31, 34, 35, 39].

Some of the secondary outcomes of this review were related to resistance in the nail bed, such as to assess data regarding artifacts that could alter the RI measurement in the nail bed, the use of resistance in the nail bed to 
characterize inflammation, and differences in RI measurements in the nail bed among patients with PsO and PsA. Four of the included studies reported the RI measurements in the nail bed with conflicting results among patients with $\mathrm{PsO}$ and PsA, indicating the need for further evaluation in future studies to better determine how to apply the measure in clinical practice, including potential differences among specific subgroups.

Regarding artifacts that could alter the RI, two studies have shown significant differences when patients with $\mathrm{PsO}$ were compared with healthy controls and also when patients with $\mathrm{PsO}$ were stratified by the presence of nail disease [31, 40]. El-Ahmed and colleagues (2011) tested whether there were significant differences on NVRI measurements among groups of individuals based on sex, age, family history of $\mathrm{PsO}$, and Psoriasis Area and Severity Index scores and no associations were found [40]. Also not all studies assessing these parameters reached statistical significance. Thus, this aspect of the disease still needs to be further investigated.

Morphologic changes, such as the thickness of nail beds, and nail plate, seem to be important parameters to analyze $[28,31,34,35,37-39,41-43]$. In fact, patients with PsA and $\mathrm{PsO}$ presented significantly higher nail bed and nail plate thickness than controls $[28,39]$; however, no study was able to predict more severe disease or the development of PsA based on this unique parameter [38].

Our review have limitations that need to be addressed, particularly the number of databases assessed and language limits, adopted due to logistic restrictions. Despite these limitations, we consider that the review was able to gather relevant and updated data about the current knowledge about the use of US to assess nail disease in PsO and PsA patients and also highlight areas for further investigation.

\section{Conclusion}

In conclusion, a significant variability across studies assessing nail disease using US in patients with $\mathrm{PsO}$ and PsA was observed. Samples were very diverse in terms of severity, disease duration and age. The measurement of thickness was the most frequently assessed parameter. Conflicting results exist on the presence of Doppler signals in the nail unit. Further studies are needed for the evaluation of the diagnostic value of this technique.

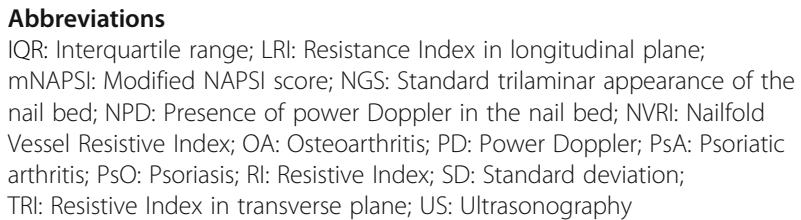

\section{Acknowledgments}

The authors thank ANOVA Consultoria em Saúde LTDA for providing scientific review support, which was funded by AbbVie in accordance with Good Publication Practice (GPP3) guidelines (http://www.ismpp.org/gpp3).

\section{Authors' contributions}

All authors made substantial contributions to conception and design, as well as acquisition, synthesis, and interpretation of data, and were also involved in writing the manuscript and given final approval of the version to be published.

\section{Funding}

ANOVA Consultoria em Saúde provided scientific review support in the development of this manuscript, funded by AbbVie.

\section{Availability of data and materials}

Not applicable due to the study nature (systematic review of previously published data).

Ethics approval and consent to participate

Not applicable once the analysis does not include human subjects.

\section{Consent for publication}

All authors read and approved the final manuscript.

\section{Competing interests}

The authors declare that they have no competing interests.

\section{Author details}

'Department of Rheumatology and Postgraduate Program of the Pontifical Catholic, University of Campinas, Rua da Fazenda, 125, Condomínio Dálias, casa 10, Residencial Vila Flora, Sumaré, São Paulo 13175665, Brazil. ${ }^{2}$ The Ottawa Hospital Research Institute, Division of Rheumatology, University of Ottawa, Ottawa, ON, Canada. ${ }^{3}$ APHP, Hôpital Ambroise Paré, Rheumatology Department, 92100 Boulogne-Billancourt, France. ${ }^{4}$ INSERM U1173, Laboratoire d'Excellence INFLAMEX, UFR Simone Veil, Versailles-Saint-Quentin University, 78180 Saint-Quentin-en-Yvelines, France.

Received: 16 September 2018 Accepted: 19 July 2019

Published online: 05 September 2019

\section{References}

1. Al-Mutairi N, Al-Farag S, Al-Mutairi A, et al. Comorbidities associated with psoriasis: an experience from the Middle East. J Dermatol. 2010;37:146-55. https://doi.org/10.1111/j.1346-8138.2009.00777.x

2. Armstrong AW, Schupp C, Bebo B. Psoriasis comorbidities: results from the National Psoriasis Foundation surveys 2003 to 2011. Dermatology. 2012;225: 121-6. https://doi.org/10.1159/000342180.

3. Azfar RS, Gelfand JM. Psoriasis and metabolic disease: epidemiology and pathophysiology. Curr Opin Rheumatol. 2008;20:416-22. https://doi.org/10.1 097/BOR.0b013e3283031c99.

4. Gottlieb AB, Chao C, Dann F. Psoriasis comorbidities. J Dermatol Treat. 2008; 19:5-21.

5. Gudjonsson JE, Elder JT. Psoriasis: epidemiology. Clin Dermatol. 2007;25: 535-46. https://doi.org/10.1016/..clindermatol.2007.08.007.

6. Meier M, Sheth PB. Clinical spectrum and severity of psoriasis. Curr Probl Dermatol. 2009;38:1-20. https://doi.org/10.1159/000232301.

7. Parisi R, Symmons DPM, Griffiths CEM, Ashcroft DM. Global epidemiology of psoriasis: a systematic review of incidence and prevalence. J Invest Dermatol. 2013;133:377-85. https://doi.org/10.1038/jid.2012.339.

8. Sociedade Brasileira de Dermatologia. Consenso Brasileiro de Psoríase 2012, 2 ed. Rio de Janeiro; 2012

9. Weigle N, McBane S. Psoriasis. Am Fam Physician. 2013;87:626-33.

10. Pasch MC. Nail psoriasis: a review of treatment options. Drugs. 2016;76:675705. https://doi.org/10.1007/s40265-016-0564-5.

11. Kaur I, Handa S, Kumar B. Natural history of psoriasis: a study from the Indian subcontinent. J Dermatol. 1997;24:230-4. https://doi.org/10.1111/ j.1346-8138.1997.tb02779.x

12. de Jong EM, Seegers BA, Gulinck MK, et al. Psoriasis of the nails associated with disability in a large number of patients: results of a recent interview with 1,728 patients. Dermatology. 1996;193:300-3.

13. Salomon J, Szepietowski JC, Proniewicz A. Psoriatic nails: a prospective clinical study. J Cutan Med Surg. 2003;7:317-21. https://doi.org/10.1007/s1 0227-002-0143-0.

14. Baran R. The burden of nail psoriasis: an introduction. Dermatology. 2010; 221:1-5. https://doi.org/10.1159/000316169. 
15. Dogra A, Arora A. Nail psoriasis: the journey so far. Indian J Dermatol. 2014; 59:319. https://doi.org/10.4103/0019-5154.135470.

16. Raposo I, Torres T. Nail psoriasis as a predictor of the development of psoriatic arthritis. Actas Dermosifiliogr. 2015;106:452-7. https://doi.org/10.1 016/j.ad.2015.02.005.

17. Kaeley GS, Eder L, Aydin SZ, et al. Enthesitis: a hallmark of psoriatic arthritis. Semin Arthritis Rheum. 2018. https://doi.org/10.1016/j.semarthrit.2017.12.008.

18. Bakewell CJ, Olivieri I, Aydin SZ, et al. Ultrasound and magnetic resonance imaging in the evaluation of psoriatic dactylitis: status and perspectives. J Rheumatol. 2013:40:1951-7. https://doi.org/10.3899/jrheum.130643.

19. Aydin SZ, Ash ZR, Tinazzi I, et al. The link between enthesitis and arthritis in psoriatic arthritis: a switch to a vascular phenotype at insertions may play a role in arthritis development. Ann Rheum Dis. 2013;72:992-5. https://doi. org/10.1136/annrheumdis-2012-201617.

20. De Agustín J, Moragues C, De Miguel E, et al. A multicentre study on highfrequency ultrasound evaluation of the skin and joints in patients with psoriatic arthritis treated with infliximab. Clin Exp Rheumatol. 2012;30:879-85.

21. Coates LC, Hodgson R, Conaghan PG, Freeston JE. MRI and ultrasonography for diagnosis and monitoring of psoriatic arthritis. Best Pract Res Clin Rheumatol. 2012;26:805-22. https://doi.org/10.1016/j.berh.2012.09.004.

22. Cunha JS, Amorese-O'Connell L, Gutierrez M, et al. Ultrasound imaging of nails in psoriasis and psoriatic arthritis. Curr Treat Options Rheumatol. 2017; 3:129-40. https://doi.org/10.1007/s40674-017-0067-x

23. Bisi MC, do Prado AD, Piovesan DM, et al. Ultrasound resistive index, power Doppler, and clinical parameters in established rheumatoid arthritis. Clin Rheumatol. 2017;36:947-51. https://doi.org/10.1007/s10067-016-3507-3.

24. Munn Z, Moola S, Lisy K, et al. Methodological guidance for systematic reviews of observational epidemiological studies reporting prevalence and cumulative incidence data. Int J Evid Based Healthc. 2015;13:147-53. https:// doi.org/10.1097/XEB.0000000000000054.

25. Joanna Briggs Institute. Joanna Briggs Institute Reviewer's Manual. Adelaide: Joanna Briggs Institute; 2017.

26. Arbault $A$, Devilliers $H$, Laroche $D$, et al. Reliability, validity and feasibility of nail ultrasonography in psoriatic arthritis. Jt Bone Spine. 2016;83:539-44. https://doi.org/10.1016/j.jbspin.2015.11.004.

27. Aydin SZ, Castillo-Gallego C, Ash ZR, et al. Vascularity of nail bed by ultrasound to discriminate psoriasis, psoriatic arthritis and healthy controls. Clin Exp Rheumatol. 2017;35:872.

28. Fassio A, Idolazzi L, Zabotti A, et al. AB0742 Ultrasonography of the nail unit in psoriasis and psoriatic arthritis: a qualitative and quantitative analysis. Ann Rheum Dis. 2017;76:1314. https://ard.bmj.com/content/76/Suppl_2/1314.2. citation-tools.

29. Paramalingam S, Taylor A, Keen H. FRI0672 Assessment of the nail bed in psoriatic arthritis (PSA) by ultrasound (US) and MRI. Ann Rheum Dis. 2017; 76:744. https://ard.bmj.com/content/76/Suppl_2/744.2.citation-tools.

30. Acquitter M, Misery L, Saraux A, et al. Detection of subclinical ultrasound enthesopathy and nail disease in patients at risk of psoriatic arthritis. Joint Bone Spine. 2017;84:703-7. https://doi.org/10.1016/j.jbspin.2016.10.005

31. Marina ME, Solomon C, Bolboaca SD, et al. High-frequency sonography in the evaluation of nail psoriasis. Med Ultrason. 2016;18:312-7. https://doi. org/10.11152/mu.2013.2066.183.hgh.

32. Mendonça JA. High specificity of spectral nail assessment in psoriatic arthritis patients. In: 2015 ACR/ARHP Annual Meeting; November 6-11, 2015. San Francisco; 2015.

33. El Miedany Y, El Gaafary M, Youssef S, et al. Tailored approach to early psoriatic arthritis patients: clinical and ultrasonographic predictors for structural joint damage. Clin Rheumatol. 2015;34:307-13. https://doi.org/10.1 007/s10067-014-2630-2.

34. Mendonça JA, Nogueira JP, Laurido IMM, et al. SAT0191 can spectral Doppler identify nail enthesitis in psoriatic arthritis? Ann Rheum Dis. 2014; 73:659. https://doi.org/10.1136/annrheumdis-2014-eular.4789.

35. Sandobal C, Carbó E, Iribas J, et al. Ultrasound nail imaging on patients with psoriasis and psoriatic arthritis compared with rheumatoid arthritis and control subjects. J Clin Rheumatol. 2014;20:21-4. https://doi.org/10.1097/ RHU.0000000000000054.

36. Aydin SZ, Castillo-Gallego C, Ash ZR, et al. Potential use of optical coherence tomography and high-frequency ultrasound for the assessment of nail disease in psoriasis and psoriatic arthritis. Dermatology. 2013;227:4551. https://doi.org/10.1159/000351702.

37. Aydin SZ, Castillo-Gallego C, Ash ZR, et al. Ultrasonographic assessment of nail in psoriatic disease shows a link between onychopathy and distal interphalangeal joint extensor tendon enthesopathy. Dermatology. 2013; 225:231-5. https://doi.org/10.1159/000343607.

38. Gisondi P, Idolazzi L, Girolomoni G. Ultrasonography reveals nail thickening in patients with chronic plaque psoriasis. Arch Dermatol Res. 2012;304:72732. https://doi.org/10.1007/s00403-012-1274-9.

39. Haddad A, Thavaneswaran A, Chandran V, Gladman DD. Clinical and ultrasonographic features of nail disease in psoriasis and psoriatic arthritis. In: 2012 ACR/ARHP Annual Meeting; November 9-14, 2012. Washington, DC; 2012

40. Husein El-Ahmed H, Garrido-Pareja F, Ruiz-Carrascosa JC, Naranjo-Sintes R. Vessel resistance to blood flow in the nailfold in patients with psoriasis: a prospective case-control echo Doppler-based study. Br J Dermatol. 2012; 166:54-8. https://doi.org/10.1111/j.1365-2133.2011.10579.x.

41. Gutierrez M, Filippucci E, De Angelis R, et al (2010) A sonographic spectrum of psoriatic arthritis: "the five targets." Clin Rheumatol 29:133-142. doi: https://doi.org/10.1007/s10067-009-1292-y.

42. Gutiérrez M, Restrepo JP, Filippucci E, Grassi W. La ultrasonografía con sondas de alta frecuencia en el estudio de la piel y la uña psoriática. Rev Colomb Reumatol. 2009;16:332-5. https://doi.org/10.1016/S0121-8123(09)70096-9.

43. Gutierrez M, Wortsman X, Filippucci E, et al. High-frequency sonography in the evaluation of psoriasis: nail and skin involvement. J Ultrasound Med. 2009;28:1569-74.

44. Mendonça JA. As diferenças do Doppler espectral, na artrite psoriática e onicomicose. Rev Bras Reumatol. 2014;54:490-3. https://doi.org/10.1016/j. rbr.2014.03.029.

\section{Publisher's Note}

Springer Nature remains neutral with regard to jurisdictional claims in published maps and institutional affiliations.

\section{Ready to submit your research? Choose BMC and benefit from:}

- fast, convenient online submission

- thorough peer review by experienced researchers in your field

- rapid publication on acceptance

- support for research data, including large and complex data types

- gold Open Access which fosters wider collaboration and increased citations

- maximum visibility for your research: over $100 \mathrm{M}$ website views per year

At BMC, research is always in progress.

Learn more biomedcentral.com/submissions 